\title{
EFFECT OF ADDING CRUSHED GLASS TO ASPHALT MIX
}

\begin{abstract}
Y. ISSA $^{1}$
The need to modify conventional pavement rises due to high maintenance cost of the highway systems. With the continuously increased consumption, a large amount of waste glass materials is generated annually in the world. This paper aims to study the performance of pavement asphalt in which a fractional aggregate is replaced with crushed glass. In this paper, some important properties of asphalt mix, including stability, flow, specific gravity and air voids are investigated. The original sample is prepared without adding glass for different percentages of bitumen. Other samples are prepared by adding crushed glass to the mix with $5 \%, 10 \%$, and $15 \%$ by aggregate weight. The results show that the properties of glass-asphalt mixture are improved in comparison with normal asphalt pavement. It is concluded that the use of waste glass in asphalt pavement is desirable.
\end{abstract}

Keywords: pavement, Asphalt performance, crushed glass, stability, and aggregate

\section{INTRODUCTION}

Asphalt modification can be made at different stages of its usage, from binder production to asphalt pavement production, and can be made by using different modifiers. Glass is considered a potentially promising modifier to asphalt. Glass is a non-metallic and inorganic material [4]. Glass can be recycled without changing its composition and properties. Glass industry has been part of human history for thousands of years. Glass is widely used in our daily life, and with the continuously increased consumption, a large amount of waste glass is generated annually. The best way to deal with these wastes is to recycle and reuse them as raw materials or modifiers [1].

\footnotetext{
${ }^{1}$ Assistant Prof. Civil Engineering Department, Fahd Bin Sultan University, Tabuk 71454, Saudi Arabia. Tel: 00966536338205, P.O Box 15700, E-mail address: yissa@fbsu.edu.sa
} 
Glass recycling can save energy and decrease environmental waste [8]. This paper study the performance of pavement asphalt in which a fractional fine aggregate is replaced with windscreen crushed glass. Since glass materials are brittle and rich in silicon, the strength and resistance to water damage of glass-asphalt pavement is higher than ordinary asphalt [14]. In 2010, Waverley- Australia constructs two sections of a road using crushed glass in pavement mixes [13]. The results of rutting tests indicated that dynamic stability of samples with maximal glass particle size of $9.5 \mathrm{~mm}$ is lower than the samples with maximal size of $4.75 \mathrm{~mm}$ [9]. At another study, examining Marshall Samples containing different percentages of glass showed that the optimum percentage of glass that can be used in the binder course is $7.5 \%$ of the weight of the aggregates [3]. In his review, Taher and others observed that fatigue and rutting resistance of asphalt mixture could be enhanced considerably by utilization of different types of additives [12]. Several studies showed that the stability declined with the increase of glass replacement. But it can be improved by introducing hydrated lime or liquid antistripping agent [11].

The same paving method used for conventional asphalt can be used for glass-asphalt in practical [7]. Greg found that the performance of the aggregate was not affected for percentages of crushed glass up to $30 \%$ by mass of aggregate [6]. The results of Ghasemi and Marandi indicate that combination of $3 \%$ rubber polymer plus $2 \%$ glass powder can improve mechanical properties of asphalt mixture considerably [5]. Asphalt pavements containing 10-15\% crushed glass in surface course mixtures have been observed to perform satisfactorily [10]. Glass comes in many forms intended for different products and applications. Glass has several types including: annealed, toughened, laminated, tempered, coated, mirrored, and patterned glass. Cars windows usually manufactured from laminated or tempered glass. Laminated glass is where two pieces of glass are attached to one another by a type of transparent plastic. Most cars windscreens are made with laminated glass because it does not shatter in sharp pieces and so does not harm the driver and passengers.

\section{EXPERIMENTAL WORK}

Various lab tests were conducted on aggregate including sieve analysis, specific gravity, and LosAngeles tests. Specific gravity test results are shown in Table 1 below. While the wear percentage of aggregate after 500 revolutions in Los-Angeles test is $21.3 \%$. 
Table (1): Specific Gravity and Absorption of Aggregate

\begin{tabular}{|c|c|}
\hline Status & Value \\
\hline BULK SP. GRAVITY (DRY BASIS) & 2.85 \\
\hline BULK SP. GRAVITY (SSD BASIS) & 3.00 \\
\hline APPARENT SPECIFIC GRAVITY & 3.34 \\
\hline ABSORPTION & $5.15 \%$ \\
\hline
\end{tabular}

On the other hand penetration test was conducted on the used bitumen. And 70/80 bitumen penetration grade was obtained. Properties of pure bitumen are shown in Table 2.

Table (2): Conventional Properties of Bitumen

\begin{tabular}{|c|c|}
\hline Item & Value \\
\hline Penetration $(0.1 \mathrm{~mm})$ & 78.1 \\
\hline Softening point (으) & 52.3 \\
\hline Flashing point (으) & 291 \\
\hline Specific gravity & 1.02 \\
\hline
\end{tabular}

The original sample is prepared without adding the crushed glass for $(4.5 \%, 5 \%$, and $5.5 \%$ bitumen) the weights in grams (gm) are shown in Table 3.

Table (3): Original Samples Preparation for Different Bitumen Percentage

\begin{tabular}{|c|c|c|c||c|c|}
\hline AGG. SIZE & $4.75 \mathrm{~mm}$ & $9.5 \mathrm{~mm}$ & $12.5 \mathrm{~mm}$ & BITUMEN & TOTAL \\
\hline \hline Weight (gm) & 340.0 & 575.0 & 231.6 & 54 & 1200.0 \\
\hline \% Weight & $28.3 \%$ & $47.9 \%$ & $19.3 \%$ & $\mathbf{4 . 5} \%$ & $100 \%$ \\
\hline Weight (gm) & 342.0 & 570.0 & 228.0 & 60 & 1200.0 \\
\hline \hline$\%$ Weight & $28.5 \%$ & $47.5 \%$ & $19 \%$ & $\mathbf{5 \%}$ & $100 \%$ \\
\hline Weight (gm) & 338.2 & 569.0 & 226.8 & 66 & 1200.0 \\
\hline \% Weight & $28.2 \%$ & $47.4 \%$ & $18.9 \%$ & $\mathbf{5 . 5} \%$ & $100 \%$ \\
\hline
\end{tabular}


After that, waste car windscreen glass was crushed by a hammer, and glass particles with diameter less than $4.75 \mathrm{~mm}$ were used in the experiments. Nine samples of crushed glass are prepared with $5 \%, 10 \%$, and $15 \%$ by the weight of total aggregates to be $(60,120$, and 180 gm) respectively. These weights were replaced from the fine aggregates as shown in table 4.

Table (4): Fine Aggregate Weights at Different Glass/Bitumen Percentage

\begin{tabular}{|c||c||c|c||c||c|}
\hline The & $\mathbf{0 \%}$ & $\mathbf{5 \%}$ & $\mathbf{1 0} \%$ & $\mathbf{1 5 \%}$ & BITUMEN \\
\hline \hline Weight (gm) & 340.0 & 280.0 & 220.0 & 160 & $\mathbf{4 . 5 \%}$ \\
\hline \hline Weight (gm) & 342.0 & 282.0 & 222.0 & 162 & $\mathbf{5 \%}$ \\
\hline \hline Weight (gm) & 338.2 & 278.2 & 218.2 & 158.2 & $\mathbf{5 . 5 \%}$ \\
\hline
\end{tabular}

mixture of aggregate and glass is heated to a temperature of $135^{\circ} \mathrm{C}$ before mixing with asphalt bitumen. The mixture was then compacted at temperature of $160 \pm 5{ }^{\circ} \mathrm{C}$. All samples were subjected to 75 blows of compaction by Marshall Hammer on each side of specimen at temperature of $145^{\circ} \mathrm{C}$.

\section{RESULTS AND DISCUSSION}

The main objective of this paper was to study the change in asphalt mixture properties after adding crushed glass from cars windshields. The tests were conducted using the standard Marshall Apparatus. Stability, flow, specific gravity and air voids of the prepared samples were recorded. The Marshall quotient (MQ, calculated as the ratio of stability to flow) may be used as a measure of the material's resistance to permanent deformation in service [15].

Results are shown in Table 5, and Fig. 1 and 2. 
Table (5): Stability and Flow Results

\begin{tabular}{|c|c|c|c|c|}
\hline RESULTS & GLASS $\% \quad$ BITUMEN $\%$ & $\underline{4.5 \%}$ & $\underline{\mathbf{5 \%}}$ & $\underline{\mathbf{5 . 5 \%}}$ \\
\hline Stability $(\mathrm{KN})$ & 0 & 11.92 & 13.47 & 14.82 \\
\hline Flow $(\mathrm{mm})$ & & 2.8 & 2.8 & 3.2 \\
\hline MQ (KN/mm) & & 4.26 & 4.81 & 4.63 \\
\hline Stability & $5 \%$ & 12.24 & 12.68 & 13.05 \\
\hline Flow & & 2.6 & 2.7 & 3.1 \\
\hline MQ & & 4.71 & 4.69 & 4.21 \\
\hline Stability & $10 \%$ & 13.65 & 13.92 & 14.18 \\
\hline Flow & & 2.6 & 2.7 & 3.3 \\
\hline MQ & & 5.25 & 5.15 & 4.29 \\
\hline Stability & $15 \%$ & 12.51 & 12.99 & 13.72 \\
\hline Flow & & 2.6 & 2.6 & 2.9 \\
\hline MQ & & 4.81 & 4.99 & 4.73 \\
\hline
\end{tabular}

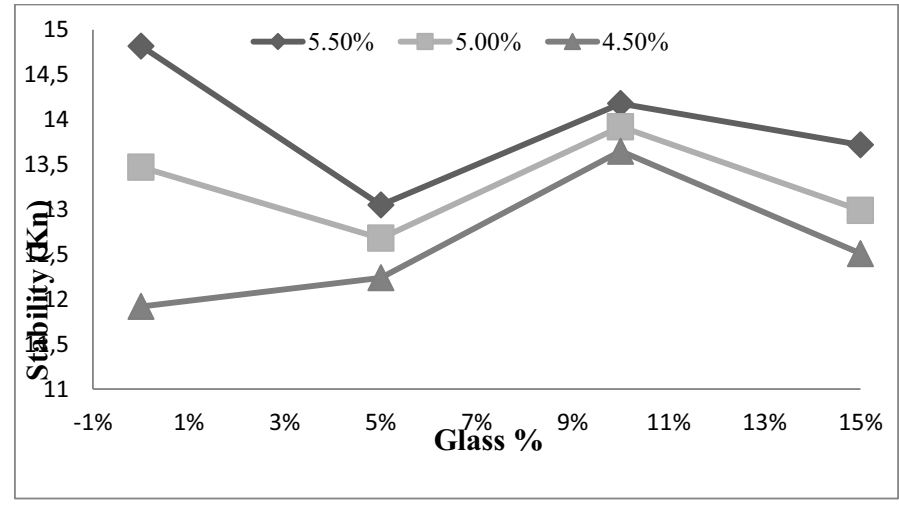

Fig. 1: Relation between stability and glass at different bitumen percentage 


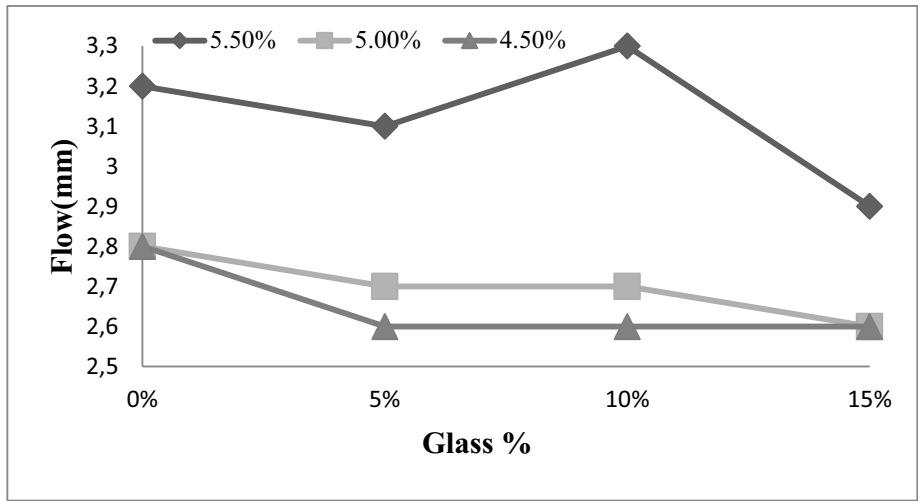

Fig. 2: Relation between flow and glass at different bitumen percentage

Comparing the results of stability and flow for asphalt-glass mix with conventional mix showed that there is an improvement at $10 \%$ glass especially at low bitumen percentage (less than 5\%). For example the stability at $4.5 \%$ bitumen at conventional mix is 11.92 while it is 13.65 at $10 \%$ asphaltglass mix; the improvement is about $15 \%$ which can be considered to be significant. Specific gravity and air voids of the samples were measured. It was found that bulk specific gravity $(\mathrm{Gmb})$ decreases with the increase of glass percentage in the mix. Air voids in the samples decreases with the increase of bitumen percentage. The average values of Marshall Test parameters with different glass percentage were summarized in Table 6 below.

Table (6): Average Marshall Test Results

\begin{tabular}{|c||c||c||c||c|}
\hline Type & $0 \%$ Glass & $5 \%$ Glass & $10 \%$ Glass & $15 \%$ Glass \\
\hline \hline Stability (KN) & 13.40 & 12.66 & 13.92 & 13.07 \\
\hline \hline Flow (mm) & 2.93 & 2.8 & 2.87 & 2.73 \\
\hline \hline Gmb & 2.40 & 2.25 & 2.13 & 2.10 \\
\hline \hline Air voids & 4.74 & 4.53 & 4.30 & 4.16 \\
\hline \hline MQ & 4.57 & 4.52 & 4.85 & 4.79 \\
\hline
\end{tabular}


From above tables, it is appeared that the average stability increased with glass addition until the maximum level (approximately $10 \%$ of glass) then it started to decrease. Average stability of asphalt without glass is higher in comparison with the asphalt with $5 \%$, and $20 \%$ glass, but lower than $10 \%$. The results showed that the stability and flow values increase with an increase in the bitumen content. The average flow of asphalt without glass is higher in comparison with the glass-asphalt. Gmb decreases with the increase of glass percentage. MQ is highest when $10 \%$ of glass is used in the mix.

Table (7) Typical Marshall Design Stability and Flow Criteria

\begin{tabular}{|c|c|c|c|c|c|c|}
\hline \multirow{2}{*}{ Mix Criteria } & \multicolumn{2}{|c|}{$\begin{array}{l}\text { Light Traffic } \\
(<104 \text { ESALs })\end{array}$} & \multicolumn{2}{|c|}{$\begin{array}{c}\text { Medium Traffic } \\
(104-106 \text { ESALs })\end{array}$} & \multicolumn{2}{|c|}{$\begin{array}{l}\text { Heavy Traffic } \\
\text { (> 106 ESALs) }\end{array}$} \\
\hline & Min & Max. & Min. & Max. & Min. & Max. \\
\hline Compaction: number of blows on each end of the sample & \multicolumn{2}{|c|}{35} & \multicolumn{2}{|c|}{50} & \multicolumn{2}{|c|}{75} \\
\hline Stability (minimum) & \multicolumn{2}{|c|}{$2.27 \mathrm{KN}$} & \multicolumn{2}{|c|}{$3.40 \mathrm{KN}$} & \multicolumn{2}{|c|}{$6.80 \mathrm{KN}$} \\
\hline Flow $(0.25 \mathrm{~mm})$ & 8 & 20 & 8 & 18 & 8 & 16 \\
\hline
\end{tabular}

(Asphalt Institute, 1997)

The above standards table (Table 7) indicated that minimum stability of Marshal Test at heavy traffic (75blows) is $6.8 \mathrm{KN}$ and flow between 2 to $4 \mathrm{~mm}$ [2]. All test values consistence with the specifications limits.

\section{CONClusion}

In this research article, a number of bitumen and asphalt samples were examined on laboratory tests. The conclusions are summarized as follows.

1. Crushed glass can be used in asphalt pavement with optimum replacement ratio of $10 \%$ by weight of total aggregates.

2. The value stability and MQ for $10 \%$ glass modified mixture was higher than the control mixture. Therefore, a significant improvement occurred in the Marshall properties of asphalt concrete mixtures using a crushed glass modifier.

3. All test values are consistent with the specifications limits. 
4. The results of this study apply only to the specific gradation and the type of glass that was used.

5. The results showed that the stability and flow values increase with an increase in the bitumen content with or without glass.

6. Other resources of glass or gradations may produce different results.

\section{REFERENCES}

1. Arnold, G, Werkmeister, S \& Alabaster, D. 'The effect of adding recycled glass on the performance of base course aggregate', NZ Transport Agency Research Report 351, New Zealand. 2008.

2. Asphalt Institute. Mix Design Methods for Asphalt, Manual Series No. 2 (MS-02). Asphalt Institute. Lexington, KY. 1997.

3. Dalloul K. "Study of the Effect of Crushed Waste Glass as Coarse Sand and Filler in the Asphalt Binder Course' Master thesis in infrastructure engineering, The Islamic University of Gaza. 2013.

4. Gautam, S, Srivastava V \& Agarwal V, 'Use of glass wastes as fine aggregate in Concrete', Journal of Academic and Industrial Research, Vol. 1(6). 2012.

5. Ghasemi M., Marandi S. M. "Laboratory Studies of the Effect of Recycled Glass Powder Additive on the Properties of Polymer Modified Asphalt Binders" IJE TRANSACTIONS A: Basics Vol. 26, No. 10, (October 2013) 1183-1190

6. Greg Arnold, Sabine Werkmeister, and David Alabaster. "The effect of adding recycled glass on the performance of basecourse aggregate”. NZ Transport Agency Research Report 351.40 pp. 2008.

7. Huang Y, Bird RN, and Heidrich O. A review of the use of recycled solid waste materials in asphalt pavements. J Conserv Recycl;52:58-73. 2007.

8. Jony, H, Al-Rubaie, M, \& Jahad, I. 'The effect of using glass powder filler on hot asphalt concrete mixtures properties', Engineering \& Technology Journal, Vol.29, No.1, pp. 44-57. 2011.

9. Marti, M. M. and Mielke, P. E. A. Synthesis Of Asphalt Recycling In Minnesota [R], Minnesota Local Road Research Board, Synthesis Report 2002-32;

10. Shafabakhsh G.H., Sajed Y. "Investigation of dynamic behavior of hot mix asphalt containing waste materials; case study: Glass cullet”. Case Studies in Construction Materials 1 (2014) 96-103. Published by Elsevier Ltd.

11. Shaopeng Wu, Wenfeng Yang \& Yongjie Xue. "Preparation and Properties of Glass-asphalt Concrete" Seventh international conference on the bearing capacity of road, rialw ays, and airfield. 27-29 June. 2005. Trondheim, Norway.

12. Taher Moghaddam, Mohamed Karim \& Mahrez Abdelaziz "A review on fatigue and rutting performance of asphalt mixes" Scientific Research and Essays Vol. 6(4), pp. 670-682, 18 February, 2011 Center for Transportation Research, University of Malaya, 50603 Kuala Lumpur, Malaysia.

13. Waverley Council "recycled glass in roads" Australian Government, Department of Sustainability, Environment, Water, Population and Communities. National Waste Policy: Case study. 2010.

14. Wu S, Yang W, and Xue Y Preparation and properties of glass-asphalt concrete. Wuham, China: Key Laboratory for Silicate Materials Science and Engineering of Ministry of Education, Wuham University of Technology. 2004.

15. Zoorob, S. and Suparma, L. "Laboratory design and investigation of the properties of continuously graded asphaltic concrete containing recycled plastics aggregate replacement (plastiphalt)", Cement and Concrete Composites, Vol. 22, No.4, (2000), 233-242 


\section{LIST OF FIGURES AND TABLES}

Fig. 1: Relation between stability and glass at different bitumen percentage

Rys. 1: Relacja pomiędzy stabilnością a szkłem przy różnych zawartościach procentowych asfaltu

Fig. 2: Relation between flow and glass at different bitumen percentage

Rys. 2: Relacja pomiędzy przepływem a szkłem przy różnych zawartościach procentowych asfaltu

Tab. 1. Specific Gravity and Absorption of Aggregate

Tab. 1. Ciężar właściwy i absorpcja kruszywa

Tab. 2. Conventional Properties of Bitumen

Tab. 2. Konwencjonalne właściwości asfaltu

Tab. 3. Original Samples Preparation at Different Bitumen Percentage

Tab. 3. Oryginalne przygotowanie próbki o różnej procentowej zawartości asfaltu

Tab. 4. Fine Aggregate Weights at Different Glass/Bitumen Percentage

Tab. 4. Ciężary drobnego kruszywa przy różnej zawartości procentowej szkła/asfaltu

Tab. 5. Stability and Flow Results

Tab. 5. Wyniki stabilności i przepływu

Tab. 6. Average Marshall Test Results

Tab. 6. Średnie wyniki testu Marshalla

Tab. 7. Typical Marshall Design Stability and Flow Criteria

Tab. 7. Typowe kryteria stabilności i przepływu projektu Marshalla 


\section{SKUTEK DODANIA KRUSZONEGO SZKLA DO MIESZANKI ASFALTOWEJ}

Słowa kluczowe: Nawierzchnia, wydajność asfaltu, szkło kruszone, stabilność i kruszywo

\section{STRESZCZENIE:}

Potrzeba modyfikacji tradycyjnych chodników narasta ze względu na wysokie koszty utrzymania systemów autostrad. Z powodu stale rosnącej konsumpcji co roku generowana jest duża ilość odpadów szklanych. Niniejszy artykuł ma na celu zbadanie wydajności nawierzchni asfaltowej, w której kruszywo frakcyjne zastępowane jest kruszonym szkłem. Niniejszy artykuł bada niektóre ważne właściwości mieszanki asfaltowej, w tym stabilność, przepływ, ciężar właściwy i pustki powietrzne. Oryginalna próbka jest przygotowywana bez dodawania szkła dla różnych zawartości procentowych asfaltu. Pozostałe próbki są przygotowywane przez dodanie kruszonego szkła do mieszanek o 5\%, 10\% i 15\% wadze kruszywa. Wyniki pokazują, że właściwości mieszanki szkło-asfalt są lepsze w porównaniu z normalnymi nawierzchniami asfaltowymi. Stwierdzono, że zastosowanie odpadów szklanych w nawierzchni asfaltowej jest pożądane.

Wyniki badania wykazały, że średnia stabilność wzrosła ze zawartością szkła do około 10\% i zmniejszała się przy wyższej zawartości szkła. Przy niskiej zawartości procentowej asfaltu średnia stabilność asfaltu bez szkła jest niska w porównaniu do asfaltu o $10 \%$ zawartości szkła. Wyniki wykazały, że wartości stabilności, przepływu i ciężaru właściwego masy wzrastają wraz ze wzrostem zawartości asfaltu. Średni przepływ asfaltu bez szkła jest wyższy w porównaniu z asfaltem zawierającym szkło. Wskaźnik MQ jest najwyższy, gdy w mieszance użyto $10 \%$ szkła. Wszystkie wartości badań są spójne z limitami specyfikacji, w których minimalna stabilność w teście Marshalla przy dużym ruchu (75 uderzeń) wynosi $6,8 \mathrm{KN}$, a przepływ między 2 a $4 \mathrm{~mm}$. 